\title{
Accounting
}

\section{Determinants of corporate performance: Empirical evidence from the insurance companies listed on Abu Dhabi securities exchange (ADX)}

\author{
Abdullah AL-Mutairi ${ }^{a^{*}}$, Hani Naser ${ }^{\mathrm{b}}$ and Kamal Naser ${ }^{\mathrm{c}}$
}

${ }^{a}$ Gulf University for Science and Technology, Kuwait

${ }^{b}$ Free Lance Senior Accounting and Financial Advisor, Kuwait

${ }^{c}$ Senior Economic and Financial Advisor, Kuwait Fund, Kuwait

\section{H R O N I C L E}

\section{Article history:}

Received: July 28, 2020

Received in revised format: July 302020

Accepted: October 2, 2020

Available online:

October 2, 2020

Keywords:

Insurance firm

Firm performance

Profitability

Abu Dhabi Securities Exchange

$(A D X)$

\section{A B S T R A C T}

The purpose of this study is to identify factors that impact the performances of the insurance companies listed on ADX. Factors employed in this study include liquidity, general and administration expenses, risk, size, tangibility and age. The annual financial statements of all seventeen insurance companies listed on ADX covering the period 2013-2019 were sampled and analyzed through a panel regression. The analysis indicates that corporate age is the most significant positive factor that determine the profitability of the insurance companies listed on ADX. The durability of the insurance company in the GCC countries suggests that the firm has created good image, attract more customers, increased revenues to cover expenses and make profit. Thus, age is an important positive factor of the performance of insurance companies listed on ADX. Moreover, it is obvious that dissatisfied customer with the service of an insurance company will not only cease dealing with it, they deliver bad news about it by using the word of mouth and the powerful social media that play efficient role in formulating the image about the company. The outcome of this study might help investors in formulating their decision to invest in an insurance company. For instance, it helps them to focus on the age of the insurance company before they make their decision.

\section{Introduction}

Determinants of insurance companies' performance received considerable attention from scholars in the finance literature. The central issue of this attention is to identify factors affecting the performance of the insurance companies. Empirical studies have shown that there is a positive relationship between the performance of insurance company measured by Return on Assets (ROA) and firm attributes. Other studies observed significant relationship between ROA and firm age and tangibility. These findings, however, seems to be questionable for the markets where governments exercise control over major economic activities such as the Gulf Co-operation Council (GCC) countries. The purpose of this study is to identify the internal variables influencing financial performances of the insurance companies listed on ADX. Identifying these variables is of interest for both investors and policy makers. For the former, it puts them in a position to compare different companies in order to make the right investment decisions at the right time. For the latter, it helps them exploring the financial position of an insurance company

\footnotetext{
* Corresponding author.

E-mail address: mutairi.a@gust.edu.kw (A. AL-Mutairi) 
before they adopt their strategic plans. Moreover, it would add dimension of literature to serve as a stepping stone for further research in GCC insurance industry.

The remainder of this study is organized as follows. Previous studies and related literature are reviewed in the following section. Data collection and model development are presented in the third section. While the findings are offered in section four, the paper ends with a conclusion.

\section{Related Literature and research hypotheses}

The concept of insurance relies upon a risk transfer practice (Najjar and Petrov, 2011). The insurance industry is part of the financial system of a country. It plays a significant role in society by offering financial security against losses form risks (Çekrezi, 2015). Healthy insurance sector is important for the population welfare and sustainable economic growth (Ejigu, 2016). It is further important for both firm management and customers as they compensate losses and set them in similar situations as they were before the loss incident (Mazviona et al., 2017). According to Chen and Wong (2004), the performance of insurance firms is affected by how much of the available funds are used in assets that earn a return as well as how big that rate of return is (Chen \& Wong, 2004).

Several studies have been undertaken to identify the factors that impact the performance of insurance companies (see for example, Jordan (Makhamreh, 2001; Almajali \& Alamro, 2012; Al-Dalaien \& Alhroob, 2017), Malaysia (Hamid et al., 2009; Ismail, 2013; Kweh \& Azizan, 2015); Pakistan (Ahmed et al., 2011; Afza \& Asghar, 2012; Saeed \& Khurram, 2015), Iran (Moghadam et al., 2012; Alenjagh, 2013), Turkey (Doğan, 2013; Kaya, 2015, 2016), India (Bawa \& Chattha, 2013; Tagra \& Dhiman, 2016), Ethiopia (Sambasivam \& Ayele, 2013; Ejigu, 2016; Meher \& Zewudu, 2020), Taiwan (Lee, 2014; Chen \& Wan, 2014), Romania (Burca \& Batrinca, 2014), Kenya (Mwangi \& Iraya, 2014; Mwangi \& Murigu, 2015), Albania (Çekrezi, 2015; Luçi et al., 2016) and Zimbabwe (Sandada et al., 2015; Mazviona et al., 2017). The following section is a brief review of the above empirical studies.

Makhamreh (2001) examined the factors behind determining the performance of insurance sector in Jordan during the period 1989-1996. He found that earnings per share (EPS) and stock prices are the best measures of corporate performance at the macro level. Makhamreh also found that stock value is the best measure of corporate performance and leadership plays significant role in affecting performance in the insurance sector. Another study performed by Almajali and Alamro (2012) who examined the factors that mostly affect financial performance of Jordanian insurance companies during the period (2002-2007). They found that leverage, liquidity, size and management competence index have a positive statistical impact on the financial performance of Jordanian insurance companies. They also found that a high consideration of increasing the company assets will lead to a good financial performance. Almajali and Alamro suggested that the insurance companies should focus on employees' efficiency by choosing the employees who complete higher educations. More recently, a study conducted in Jordan by Al-Dalaien and Alhroob (2017) who analysed the financial performance of three insurance companies namely Middle East Insurance Company, Jordan Insurance Company, and National Insurance Company during the period 2006-2015. They suspected that Middle East Insurance to face financial distress in near future. They also predicted that the National Insurance Company and Jordan Insurance Company would have fewer chances to face financial distress in the near future. They recommended that the companies have to take measures in advance to avoid any financial distress in future.

Hamid et al. (2009) attempted to identify the determinants of corporate demand for Islamic insurance (takaful) of public listed companies at Bursa Malaysia during the period from year 2002-2006. They found that leverage, expected bankruptcy costs, tax considerations, company size, and managerial ownership play important role in determining the corporate demand for Islamic insurance in Malaysia. Another study conducted by Ismail (2013) who examined the determinants of financial performance of general Islamic and conventional insurance companies in Malaysia using panel data over the period 2004- 2007. They found that the size of company and solvency margin are statistically significant determinants of the investment performance of the general Islamic insurance companies in Malaysia. Also, Kweh and Azizan (2015) used data envelopment analysis (DEA) to evaluate the managerial efficiency and profitability efficiency of Malaysia-incorporated companies for the period 2008-2011. They found that the sample firms should first improve their managerial efficiency, and then improve their profitability efficiency.

Ahmed et al. (2011) examined the impact of firm's characteristics on the performance of listed life insurance companies in Pakistan over seven years from 2001 to 2007. They found that size, risk and leverage are important determinants of the performance of life insurance companies of Pakistan while ROA has statistically insignificant relationship with growth, profitability, age and liquidity. Another study conducted by Afza and Asghar (2012) who examined the performance determinants for general insurers over the period 2004- 2009. They found that size, investment, past performance and age are positively related; whereas, leverage and risk are negatively related with the performance of general insurers. They also found economic uncertainty has adverse effect on the performance of general insurers. Another study performed by Saeed and 
Khurram (2015) tested the factors influencing the financial performance of non-life insurance companies of Pakistan. They found that age and loss ratio are proven significant in determining the financial performance whereas growth of premium, size of firm, debt and expense ratio proved insignificant. Moghadam et al. (2012) compared the performance of different insurance companies in Iran. They found that Iran, Asia and Alborz insurance firms have the most premium manufacturing, while insurance of Dey and Mihan have good growth in the same period. Another study was conducted by Alenjagh (2013) to evaluate financial performance of five companies in the insurance sector active in the Tehran Stock Exchange. He found that the level of liquidity is the most important to assess the performance of insurance companies.

Doğan (2013) examined the impact of capital structure, within the insurance companies listed on in Istanbul Stock Exchange during the years 2005-2011, on profitability. He found that a negative relationship between the profitability of the insurance companies, financial leverage and age. He also found a positive relationship between profitability and the company size. Kaya (2015) examined the firm-specific factors affecting the profitability of non-life insurance companies operating during the period 2006-2013. They found that the firm-specific factors affecting the profitability of Turkish non-life insurance companies are size, age, loss ratio, current ratio, and premium growth rate. Furthermore, Kaya (2016) examined the financial performance of non-life insurance companies traded in Borsa Istanbul during the period 2010 to 2014. The researcher found that profitability ratios have the greatest impact on the financial performance of non-life insurance companies traded in Borsa Istanbul. He concluded that a non-life insurance company can provide sustainable profitable growth.

Bawa and Chattha (2013) examined 18 Indian life insurers including 1 public and 17 private firms during the period $2007-2012$ and found profitability positively influenced by liquidity and size and negatively related to capital. They also found that profitability does not have any association with solvency and insurance leverage. Another study was conducted by Tagra and Dhiman (2016) who explored the growth of insurance sector in India. They observed that insurance policy is purchased by the policy holders for investment or tax saving purpose and not for protection. They concluded that government should frame appropriate guidelines and make mandatory for the concerned agencies and agents to educate the policy holders about the core benefits and risk factors of insurance products.

Sambasivam and Ayele (2013) examined the impact of firm specific factors (corporate age, size, volume of capital, leverage ratio, liquidity ratio, growth and assets tangibility) on profitability represented by ROA during the period of 2003-2011. They found that growth, leverage, volume of capital, size, and liquidity are identified as the most important determinant factors of profitability. They also found that the liquidity and leverage ratios are negatively but significantly related with profitability. They also observed that the age of companies and tangibility of assets are not significantly related to profitability. Another study was conducted by Ejigu (2016) to identify the factors affecting the financial performance of insurance companies in Ethiopia during the period 2005-2012. They found that leverage, liquidity, company size, management competence index and company growth rate are influential factors of financial performance. The researcher also found that company age and loss ratio have no impacts on the financial performance of insurance companies in Ethiopia. He recommended that companies should attempt to find more internally generated sources of finance and equity financing than debt financing. More recently, Meher and Zewudu (2020) looked into the effect of internals and macroeconomic factors on financial performance of nine Ethiopian insurance companies during the period 2002-2016. They reported positive and significant association between corporate profitability and gross domestic product (GDP) per capita and the size, negative and significant association detected between corporate profitability and leverage, liquidity and underwriting risk. They concluded that assets growth steps up financial performance as a result of opening more branches. They further concluded that reduction in of underwriting risk, capital structure management together with minimum dependence on borrowing, and deployment of premium earned accelerates the financial performance of insurance companies. Lee (2014) examined the relationship between firm specific factors and macroeconomic factors on the profitability of Taiwanese property-liability insurance industry during the period 1999-2009. He found that underwriting risk, reinsurance usage, input cost, return on investment and financial holding group have significant influence on profitability in both operating ratio and ROA. Another study conducted by Chen and Wan (2014) to analyze the relationship between corporate image and business operation of life insurance companies in Taiwan found that both underwriting and financial operations have considerable impact on the corporate image of life insurance companies.

Burca and Batrinca (2014) explored the determinants of the financial performance in Romanian insurance market during the period 2008-2012. They found financial leverage, corporate size, growth in gross written premiums, underwriting risk, risk retention ratio and solvency margin are the main determinants of the financial performance. They concluded that the fact that Romania insurance companies are facing the combined effects of deteriorating market conditions and the impact of the financial crisis. Mwangi and Iraya (2014) assessed the determinants of financial performance of general insurance underwriters in Kenya during the period 2010-2012. They found that financial performance is positively related to earning assets and investment yield. They also found that financial performance is negatively related to loss and expenses ratios. They concluded that there is a need for general insurance firms to focus on the investment operations, underwriting results and efficiency. Another study was performed by Mwangi and Murigu (2015) to examine the determinants of financial performance in general insurance companies for the period 2009- 2012. They found that profitability is positively related with leverage, equity capital, management 
competence index and negatively related to size and ownership structure. They recommended that insurers in Kenya should increase leverage, equity capital and quality of staff. Çekrezi (2015) explored factors that affect financial performance of Albanian insurance companies during the period 2008- 2013. The researcher found that risk has negative impact and tangibility has positive impact on the financial performance ROA of these companies. Another study carried out by Luçi et al. (2016) assessed the impact of internal factors, growth rate, liquidity, liability, fixed assets, company size and capital volume, on the profitability of insurance companies in Albania during the period 2008- 2013. They found a statistically significant relationship between growth rate, liquidity, liabilities and fixed assets and the profitability of insurers, while the impact of factors of company size and the volume of capital was statistically insignificant. Sandada et al. (2015) examined the impact of the board of directors' characteristics on the performance of insurance firms. They found that the board characteristics, board composition, diversity, and size, have significant positive predictive relationship with the performance of non-life insurance firms. They suggested that non-life insurance companies should be aware of board characteristics in order to improve their performance. Mazviona et al. (2017) examined factors affecting the performance of the insurance companies during the period 2010-2014. They found that the expense ratio, claims ratio and the size of a company significantly and negatively affect insurance companies' performance. They also found that leverage and liquidity affect performance positively. They recommended that insurance companies should introduce mechanisms that reduce operational costs.

Concerning the GCC region, few studies have been undertaken to examine the performance of insurance companies (see for example, Bahrain (Najjar \& Petrov, 2011), Saudi Arabia (Saaty, 2012) and Kuwait (Merza \& Almusawi, 2016). The following section reviews in brief these studies. Najjar and Petrov (2011) examined the impact of firm characteristics on the capital structure of the insurance industry for the period of 2005-2009. They found a strong relationship between capital structure represented by the debt ratio and firm characteristics namely tangibility of assets, profitability, firm size, growth revenue and liquidity. Saaty (2012) examined the attitudes of people towards insurance companies. He found that people are reluctant to buy insurance other than compulsory insurance because they believe that insurance against the Islamic principles. He concluded that the insurance companies need to focus on inviting people on awareness and education programs to remove the barriers in the minds of the customers and enhance the customer loyalty and customer retention. Merza and Almusawi (2016) attempted to identify the factors behind affecting the performance of insurance sector for the period 2005-2015. They found that the insurance sector is influenced by money supply, residential real estate price and oil price.

It is evident that a limited number of empirical studies have been undertaken to assess the performance of insurance sector in GCC region. It suggests the need for further empirical testing to enhance our understanding of determinants of internal factors behind the performance of insurance companies listed on ADX. Hence, this study is undertaken to test following hypotheses:

Hypothesis 1 : There is a relationship between firm's liquidity and the profitability of the insurance companies listed on $A D X$.

Hypothesis 2 : There is a relationship between firm's general and administrative expenses and the profitability of the insurance companies listed on $A D X$.

Hypothesis 3 : There is a relationship between firm's risk and the profitability of the insurance companies listed on $A D X$.

Hypothesis 4 : There is a relationship between firm's size and profitability of the insurance companies listed on $A D X$.

Hypothesis 5 : There is a relationship between firm's tangibility and the profitability of the insurance companies listed on $A D X$.

Hypothesis 6 : There is a relationship between firm's age and the profitability of the insurance companies listed on $A D X$.

\section{Data Collection and Study Methodology}

Data used in this study were mainly extracted from Abu Dhabi Securities Exchange (ADX) website. 17 insurance companies were listed on ADX. The website displayed the annual reports for all listed companies for the period between 2013- 2019. Data were collected about all listed companies during this period. Hence, the choice of the covered period was determined by data availability. Table 1 contains the names of companies listed on ADX and covered in this study. The dependent variable adopted in this study is Return on Assets (ROA) and the independent variables are liquidity (LIQ), general and administration expenses (GAE), risk (RIS), size (SIZ), tangibility (TAN) and corporate age (AGE). The independent variables are drawn from previous studies such as Hamid et al. (2009); Ismail (2013) in Malaysia; Ahmed et al. (2011); Afza and Asghar (2012); Saeed and 
Khurram (2015) in Pakistan; Najjar and Petrov (2011) in Bahrain; Almajali and Alamro (2012) in Jordan; Alenjagh (2013) in Iran and Meher and Zewudu, 2020 in Ethiopia.

Table 1

List of companies

\begin{tabular}{clll}
\hline No. & Company Name & No. & Company Name \\
\hline 1. & Abu Dhabi National Insurance Company & 10. & United Fidelity Insurance Company (P.S.C) \\
2. & Al Buhaira National Insurance Company & 11. & Insurance House \\
3. & Al Fujairah National Insurance Company & 12. & Methaq Takaful Insurance Compnay \\
4. & Al Khazna Insurance Co. & 13. & Ras Alkhaima National Insurance Co. \\
5. & Al Ain Alahlia Insurance Co. & 14. & Sharjah Insurance Company \\
6. & Al Wathba National Insurance Co. & 15. & Abu Dhabi National Takaful Co. \\
7. & AXA Green Crescent Insurance Company PJSC & 16. & Union Insurance Company \\
8. & Al Dhafra Insurance Co. & 17. & National Takaful Company (Watania) \\
\hline 9. & Emirates Insurance Co. & & \\
\hline
\end{tabular}

Thus, the relationship between dependent variable and independent variables is estimated by using the following regression model:

$$
P E R=\alpha+\beta_{1} L I Q+\beta_{2} G A E+\beta_{3} R I S K+\beta_{4} S I Z+\beta_{5} T A N+\beta_{6} A G E+\varepsilon
$$

$\begin{array}{ll}\text { Where: } & =\text { Performance measured by the Return on Total Assets } \\ \text { PER } & =\text { Intercept } \\ \alpha & =\text { Liquidity measured by the Current Ratio } \\ \text { LIQ } & =\text { Annual General and Administration Expenses/ Gross Primmum } \\ \text { GAE } & =\text { Risk measured by Total Liabilities/ Total Assets. } \\ \text { RISK } & =\text { Size measured by the natural logarithm of Gross premiums. } \\ \text { SIZE } & =\text { Tangibility measured by Fixed Assets/ Total Assets. } \\ \text { TAN } & =\text { Age is number of years since the date of incorporation. } \\ A G E & =\text { Parameters of the model } \\ \beta_{1-} \beta_{5} & =\text { Standard Error } \\ \varepsilon & \end{array}$

\section{Findings}

\subsection{Descriptive statistics}

Descriptive statistics about the dependent and independent variables employed in this study are summarized in Table 2. It is obvious from the table that the age of the insurance companies covered in this study ranges between 2 and 49 years. The table also disclosed that the overall performance of the covered companies measured by the return on assets was positive (1.1\%). However, several companies at various years sustained losses. The mean of the covered companies' liquidity measured by the current ratio was around two times and ranges between 0.579 and 7.989 . The general and administration expenses accounted in average for about $17 \%$ of the gross premiums of the insurance companies. What attracts attention in Table 2 is in one year the general and administration expenses were about 1.5 times the gross premiums. The table further revealed that, in average, almost $61 \%$ of the insurance companies' assets are financed by liabilities. The mean of the companies' gross premiums was around AED 504 million and ranges between AED 21 million and AED 3.8 billion. Finally, the average fixed assets to total assets was about $46 \%$ and ranges between $20 \%$ and $85 \%$.

Table 2

Descriptive Statistics

\begin{tabular}{cccccc}
\hline & Mean & Median & Maximum & Minimum & Std. Dev. \\
\hline ROA & 0.011 & 0.024 & 0.127 & -0.221 & 0.057 \\
LIQ & 2.033 & 1.298 & 7.989 & 0.579 & 1.576 \\
GAE & 0.169 & 0.125 & 1.476 & 0.015 & 0.186 \\
RIS & 0.629 & 0.636 & 1.713 & 0.271 & 0.208 \\
SIZ & 19.482 & 19.442 & 22.047 & 16.857 & 1.061 \\
TAN & 0.461 & 0.447 & 0.853 & 0.198 & 0.155 \\
AGE & 27.059 & 34.500 & 49.000 & 2.000 & 15.222 \\
\hline
\end{tabular}




\subsection{Unit root tests}

Regression analysis based on non-stationary data leads to spurious results. Pooled data variables are usually not stationary since it is difficult to maintain the data mean, variance and auto covariance constant over time. Therefore, the unit root test was performed. The outcome of the test is presented in Table 3.

Table 3

Unit Root Test

\begin{tabular}{llll}
\hline Variable & & & At level \\
\cline { 3 - 4 } & $\boldsymbol{L I Q}$ & $\boldsymbol{t}$ - Statistic & Prob. \\
\hline $\boldsymbol{G A E}$ & -5.25178 & 0.0000 \\
& $\boldsymbol{R I S}$ & -4.98308 & 0.0000 \\
& $\boldsymbol{S I Z}$ & -5.89915 & 0.0004 \\
& $\boldsymbol{T} \boldsymbol{N}$ & -4.67767 & 0.0000 \\
& $\boldsymbol{A} \boldsymbol{G E}$ & -5.18419 & 0.0000 \\
\hline
\end{tabular}

\subsection{Correlations}

Table 4 summarises correlations among all variables included in the regression model. It is evident from the table that corporate profitability measured by ROA is significantly correlated with all independent variable except for the liquidity and age variables. Significant correlations also appeared between the independent variables. However, the value of Durbin-Watson value appears in Table 5 is 1.828. Durbin-Watson defined no correlation area between 1.70 and 2.30. This indicates that collinearity is not a serious problem.

Table 4

Correlations among the variables used in the regression model

\begin{tabular}{|c|c|c|c|c|c|c|c|}
\hline & $R O A$ & $L I Q$ & $G A E$ & $R I S$ & $S I Z$ & $T A N$ & $A G E$ \\
\hline$R O A$ & 1.000 & & & & & & \\
\hline$L I Q$ & 0.005 & 1.000 & & & & & \\
\hline $\boldsymbol{G} \boldsymbol{A} E$ & $-.344^{* *}$ & -0.066 & 1.000 & & & & \\
\hline$R I S$ & $-.254^{*}$ & $-0.316^{* *}$ & -0.0009 & 1.000 & & & \\
\hline$S I Z$ & $.298^{* * *}$ & $0.204^{*}$ & $-.605^{* *}$ & $.247^{* *}$ & 1.000 & & \\
\hline$T A N$ & $-.388^{* *}$ & -0.061 & $.189^{*}$ & -0.171 & $-.342^{* *}$ & 1.000 & \\
\hline$A G E$ & 0.130 & 0.045 & $-.233^{* *}$ & 0.053 & $.339^{* *}$ & -0.006 & 1.000 \\
\hline
\end{tabular}

**. Correlation is significant at the 0.01 level (2-tailed).

*. Correlation is significant at the 0.05 level (2-tailed).

\subsection{Model Estimation}

Before estimating the regression model, it was important to run Hausman test. The test helps in identifying a statistical model suitable for the data. The choice is between fixed or random effects where the null hypothesis is that the preferred model is random effects versus the fixed effects. If after performing the test the p-value is significant (for example $<0.05$ ), the fixed effect is employed. Table 5 contains the result of Hausman test and demonstrated that p-value is significant. Hence, the fixed effect is used and the outcome of the regression analysis is summarized in Table 6.

Table 5

Hausman Test

\begin{tabular}{llll}
\hline Test Summary & Chi-Sq. Statistic & Chi-Sq. d.f. & Prob. \\
\hline Cross-section random & 28.743906 & 6 & 0.0001 \\
\hline
\end{tabular}

It is evident from the table that corporate age is the most significant variable positively associated with corporate profitability of the insurance companies listed on Abu Dhabi Securities Exchange. This result is consistent with previous studies undertaken by Afza and Asghar (2012), Saeed and Khurram (2015), Kaya (2015). The result is, however, inconsistent with Doğan (2013) who reported negative and significant association between the two variables. The result is, further, not in line with Sambasivam and Ayele (2013) and Ejigu (2016) who reported insignificant association between the profitability of the insurance companies and corporate age. The result reflects the nature of the Arab culture, in general, and the culture of the Gulf Cooperation Council (GCC) countries, in particular. The opinion of the GCC citizens about insurance companies is determined by their experience with these companies. It is well known, in the Arab countries that insurance companies lack the credibility of the insurance companies in developed countries. Citizens in the GCC countries are interested in obtaining compensation from the insurance company when they make claims. An idea about the insurance company will be formed 
by the beneficiaries through their special experiences that they often spread to other beneficiaries. Hence, there is no place for companies fail to provide good services to their clients. Increasing the age of the insurance company in the GCC countries means that the company gained consumer's confidence. This will result in an increase in its market share at the expense of companies that did not convince clients. Clients who dissatisfied with the service of an insurance company will not only stop dealing with it, they spread bad news about it by using the word of mouth and the powerful social media that play effective role in formulating the image about the company. Therefore, word of mouth and social media play a vital role in the survival of the insurance company. The longevity of the insurance company in the GCC countries implies that the company has established good image, attract more customers, increased revenues to cover expenses and make profit. Thus, age is a significant positive determinant of the performance of insurance companies listed on ADX.

\section{Table 6}

The results of OLS

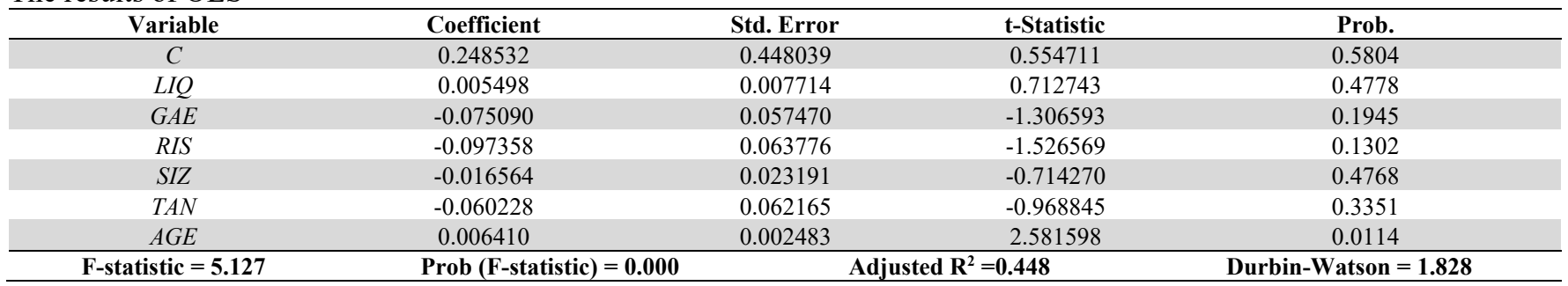

\section{Conclusion}

This study is set out to explore factors impact the profitability of the insurance companies listed on ADX. To achieve this objective, data were collected from the website of ADX about all companies listed on the exchange during the period 20132019. Return on assets (ROA) was used in this study to proxy corporate profitability. Six explanatory variables frequently adopted in previous research and it was possible to collect data about them were used in this study. It was evident from the analysis that corporate profitability is positively and significantly influenced by corporate age. Although the level of liquidity appeared to be positively associated with the insurance companies' profitability, the association was insignificant. However, the remaining explanatory variable employed in this study showed insignificant negative association with corporate profitability.

\section{References}

Adams, M. \& Buckle, M. (2000). The determinants of operational performance in the Bermuda insurance market. Applied Financial Economics, 1(2), 133-143. http://dx.doi.org/10.1080/09603100210105030

Afza, T. \& Asghar, M. (2012). Determinants of performance in the general insurers of Pakistan. Actual Problems of Economics, 1(138), 286-292. DOI: 10.2139/ssrn.2007534

Ahmed, N., Ahmed, Z., \& Usman, A. (2011). Determinants of performance: A case of life insurance sector of Pakistan. International Research Journal of Finance and Economics, 61(January), 123-128.

Al-Dalaien, B. \& Alhroob, M. (2017). Financial performance analysis of Jordanian insurance companies using the Altman zscore model. International Journal of Academic Research and Development, 2(1), 24-29

Ajao, M. G., \& Ogieriakhi, E. (2018). Firm specific factors and performance of insurance firms in Nigeria. Amity Journal of Finance, 3(1), 14-28.

Alenjagh, R. (2013). Performance evaluation and ranking of insurance companies in Tehran Stock Exchange by financial ratios using ANP and PROMETHEE. European Online Journal of Natural and Social Sciences, 2(3), 3478-3486

Almajali, A. \& Alamro, S. (2012). Factors affecting the financial performance of Jordanian insurance companies listed at Amman stock exchange. Journal of Management Research, 4(2), 266-289. https://doi.org/10.5296/jmr.v4i2.1482

Bawa, S., \& Chattha, S. (2013). Financial performance of life insurers in Indian insurance industry. Pacific Business Review International, 6(5), 44-52

Burca, A., \& Batrinca, Gh. (2014). The determinants of financial performance in the Romanian insurance market. International Journal of Academic Research in Accounting, Finance and Management Sciences, 4(1), 299-308, DOI: 10.6007/IJARAFMS/v4-i1/637

Çekrezi, A. (2015). Determinants of financial performance of the insurance companies: A case of Albania. International Journal of Economics, Commerce and Management, 3(4),1-10

Chen, T., \& Wan, A. (2014). The determinants of corporate image for life insurers in Taiwan. Asia-Pacific Journal of Risk and Insurance; Singapore, 8(2), 205-228. DOI: 10.1515/apjri-2013-0020

Chen, R., \& Wong, K. (2004). The determinants of financial health of Asian insurance companies. The Journal of Risk and Insurance, 71(3), 469-499 
Doğan, M., (2013). Relations between the profitability and capital structure of insurance companies: An analysis over Turkish capital market. The Journal of Accounting and Finance, 57(January),121-136.

Ejigu, S. (2016). Determining internal factors affecting financial performance of insurance companies in Ethiopia. Research Journal of Commerce \& Behavioural Science, 5(6),9-21

Hamid, M., Osman, J., \& Nordin, B. (2009). Determinants of corporate demand for Islamic insurance in Malaysia. International Journal of Economics and Management, 3(2), 278-296

Ismail, M. (2013). Determinants of financial performance: The case of general takaful and insurance companies in Malaysia. International Review of Business Research Papers, 9(6), 111-130

Iswatia, S., \& Anshoria, M. (2007). The influence of intellectual capital to financial performance at insurance companies in Jakarta Stock Exchange (JSE). Proceedings of the $13^{\text {th }}$ Asia Pacific Management Conference, Melbourne, Australia.

Kaya, E. (2015). The effects of firm-specific factors on the profitability of non-life insurance companies in Turkey. International Journal of Financial Studies, 3(4), 510-529. http://dx.doi.org/10.3390/ijfs3040510

Kaya, E. (2016). Financial performance assessment of non-life insurance companies traded in Borsa Istanbul via Grey relational analysis. International Journal of Economics and Finance; 8(4), 277-288. doi:10.5539/ijef.v8n4p277

Kweh, Q., \& Azizan, N. (2015). Efficiency performance of general insurance companies in Malaysia. Journal of Advanced \& Applied Sciences, 3(4), 119-124

Lee, Ch. (2014). The effects of firm specific factors and macroeconomics on profitability of property-liability insurance industry in Taiwan. Asian Economic and Financial Review, 4(5), 681-691

Luçi, E., Kripa, D., \& Ajasllari, D. (2016). Assessment of insurance companies profitability: case of Albania. International scientific conference- ERAZ: Knowledge based sustainable economic development, Belgrade, 16, 351-362

Makhamreh, M. (2001). Corporate performance in Jordan: Analysis and evaluation. Administrative Sciences, Dirasat Journal, 28 (1), 194-229

Mazviona, B., Dube, M., \& Sakahuhwa, T. (2017). An analysis of factors affecting the performance of insurance companies in Zimbabwe. Journal of Finance and Investment Analysis, 6(1),11-30.

Meher, K. C., \& Zewudu, D. (2020). Determinants of Firm's Internals \& Macroeconomic Factors on Financial Performance of Ethiopian Insurers. DLSU Business \& Economics Review, 29(2), 71-80.

Merza, E., \& Almusawi, S. (2016). Factors affecting the performance of Kuwait Stock Market. Journal of Sustainable Development, $9(5), 23-32$, doi:10.5539/jsd.v9n5p23

Moghadam, K., Atefi, Z., Barati, P., Omidi, M., \& Zoghi, A. (2012). Performance comparison of insurance companies. Institute of Interdisciplinary Journal of Contemporary Research in Business, 4(7), 259-264

Mwangi, M., \& Iraya, C. (2014). Determinants of financial performance of general insurance underwriters in Kenya. International Journal of Business and Social Science, 5(13), 210-215

Mwangi, M., \& Murigu, J. (2015). The determinants of financial performance in general insurance companies in Kenya. European Scientific Journal, 11(1), 288-297

Najjar, N., \& Petrov, K. (2011). Capital structure of insurance companies in Bahrain. International Journal of Business and Management, 6(11), 138-145, doi:10.5539/ijbm.v6n11p138

Saaty, A. (2012). An empirical analysis of the strategies undertaken by insurance companies in Saudi Arabia to enhance customer loyalty and customer retention. International Journal of Economics and Management Sciences, 1(11),20-25

Saeed, U., \& Khurram, N. (2015). Factors influencing the financial performance of non-life insurance companies of Pakistan. International Journal of Empirical Finance, 4(6),354-361

Sambasivam, Y., \& Ayele, A. (2013). A study on the performance of insurance companies in Ethiopia. International Journal of Marketing, Financial Services \& Management Research, 2(7),138-150

Sandada, M.; Manzanga, N. \& Shamhuyenhanzva, R. (2015). How do Board Characteristics influence business performance? Evidence from non-life insurance firms in Zimbabwe. Acta Universitatis Danubius: Oeconomica, 11(4), $103-116$.

Tagra, P. \& Dhiman, P. (2016). Insurance sector growth and performance: An analysis. Saudi Journal of Business and Management Studies, 1(3),91-94. DOI: 10.21276/sjbms.2016.1.3.3

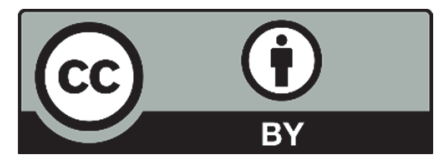

(C) 2020 by the authors; licensee Growing Science, Canada. This is an open access article distributed under the terms and conditions of the Creative Commons Attribution (CC-BY) license (http://creativecommons.org/licenses/by/4.0/). 